\title{
Effect of species, breeds, season and stage of lactation on urea content of milk and its variation during processing of milk and milk products
}

\author{
Hitesh Patel and Raman Seth
}

Received: 23 March 2019 / Accepted: 12 June 2019 / Published online: 27 August 2019

(C) Indian Dairy Association (India) 2019

\begin{abstract}
Urea levels in milk of different species and its breeds; effect of season, stage of lactation and its relationship with fat, SNF and milk yield was investigated. Effect of various processing treatments on changes in urea content of milk and milk products were evaluated. Pooled samples of buffalo (Murrah) and cows (Tharparkar, Sahiwal and Karan Fries) were collected and urea content was estimated over a period of ten days. Average urea content in milk of Murrah, Tharparkar, Sahiwal and Karan Fries was found to be $41.38,40.85,38.2$ and $25.53 \mathrm{mg} / 100 \mathrm{ml}$, respectively. For both the species studied urea content in milk was influenced by season and it was significantly higher in winter and lower in summer and intermediate in rainy season. Milk urea content was observed to be significantly lower in colostrum of Sahiwal and Murrah; however it was maximum during $2^{\text {nd }}$ and $3^{\text {rd }}$ month of lactation in comparison to normal milk. During stage of lactation, the study revealed negative relationship between urea with fat, SNF content and positive relationship with milk yield. Processing treatments of milk significantly affected the urea level. During Pasteurization $\left(63^{\circ} \mathrm{C} / 30 \mathrm{~min}\right)$ and boiling $(2$ to $5 \mathrm{~min}$ ) of milk, urea level was increased, whereas during sterilization $\left(121^{\circ} \mathrm{C} /\right.$ $15 \mathrm{~min}$ ), urea level decreased. The average urea content in dahi,
\end{abstract}

Hitesh Patel ( $\square)$ and Raman Seth

Dairy Chemistry Division

ICAR-National Dairy Research Institute, Karnal, Haryana, India

Email:phdhitesh93@gmail.com; Phone: +91-9783103311;

+91-7878987324 khoa, skim milk powder (roller dried), paneer and paneer whey was found to be $18.78,184.60,408,1.67$ and $40.67 \mathrm{mg} / 100 \mathrm{~g}$, respectively.

Keywords: Milk products, Processed milk, Season, Stage of lactation, Urea content

\section{Introduction}

Urea is normal constituent of milk and forms a major part of nonprotein nitrogen of milk. It is also a common constituent of blood and naturally occurring excretory end product. There is positive correlation between urea concentration in plasma and milk. Perhaps, blood urea is affected by various nutritional factors such as high or low nitrogen intake in the diet, water, dry matter, degradable or undegradable protein and other factors such as species, breed, season, stage of lactation, age etc. These factors influence the urea concentration in blood which subsequently influences the concentration of milk urea. Excess concentration of urea in the blood can also affect milk production, reproductive efficiency, embryo survivability and immune function of animals (Dominic et al., 2014).

Although India is the largest milk producer in the world, demand of milk is more compared to production in the country. Due to this gap, some middle men add some cheap adulterants into milk to increase the quantity and earn profit. Among these, urea is one of the common adulterant added in milk to increase the SNF content. High level of urea in milk may causes health problem like indigestion, acidity, ulcers, cancer, malfunctioning of kidneys, osteoporosis and gradual impairment of the body (Abdallah et al., 2008). It is also very harmful especially to young girls as it hastens the process of puberty (Singh and Gandhi, 2015).

It is very important from the public health point of view to evaluate the levels of urea in raw milk and changes occurring during processing of milk and milk products. According to the Food Safety Standard Regulations (FSSR, 2011), the permissible maximum urea level in raw milk is $700 \mathrm{ppm}$. However, there is no systematic study about the level of urea content in milk of different species and their breeds, as well as changes during processing of milk and milk products. Hence the present study 
was aimed to conduct an exploratory survey of urea concentration in different species and effect of non-nutritional parameters such as seasonal variation, lactation and their relation with fat, SNF and milk yield. Further the effect of processing conditions on urea content of different milk products was also estimated.

\section{Materials and Methods}

\section{Collection of milk samples}

Milk samples were collected from different breeds of cow and buffalo from Livestock Research Centre, National Dairy Research Institute, Karnal, India. Pooled milk samples (500 ml) of different breeds of cow (Sahiwal (SW), Tharparkar (TP), Karan Fries (KF)) and buffalo (Murrah) were collected at 10 days interval for one year and analysed for fat, solids not fat (SNF) and urea (mg/ 100 $\mathrm{ml}$ ) content in milk. Further the effect of season i.e. summer (March - June), winter (November - February) and rainy (July - October) on fat, SNF and urea content in milk of different breeds of cow and buffalo was also investigated.

Individual milk samples of SW cow and Murrah buffalo were collected for analysis of fat, SNF and urea content at 15 days intervals after calving to its drying period and effect of stage of lactation on fat, SNF, milk yield and milk urea level was studied. Relationship of fat, SNF and yield with milk urea was also investigated.

Pooled milk samples were collected from SW cow and Murrah buffalo separately to study the effect of processing on milk i.e. pasteurization $\left(63^{\circ} \mathrm{C} / 30 \mathrm{~min}\right)$, boiling (for 2 and $5 \mathrm{~min}$ ) and sterilization $\left(121^{\circ} \mathrm{C} / 15 \mathrm{~min}\right.$ at $\left.15 \mathrm{PSI}\right)$. Similarly milk products like dahi, khoa, skim milk powder, paneer were prepared from mixed milk as per the standard procedure (De, 1991; Aneja et al., 2002) to check urea level during conversion of milk to milk products.

\section{Compositional analysis}

Raw milk samples of different species (Murrah buffalo and SW cow) were collected for analysis of fat, SNF and urea. The urea content in milk was determined using $p$-Dimethyl Amino Benzaldehyde (DMAB) method described by Bector et al. (1998). Fat content in milk was determined by Gerber method (IS, 1977) and SNF content in milk was determined using lactometer (IS, 1982). Total solids content in khoa and skimmed milk powder was determined as per the standard methods (IS, 1995; IS, 1997).

\section{Urea estimation from dairy products:}

For estimation of urea content in dairy products (Dahi, Khoa and Paneer), $10 \mathrm{~g}$ of sample was weighed in the beaker and $10 \mathrm{ml}$ hot water $\left(50^{\circ} \mathrm{C}\right)$ was added to make uniform slurry. The content of the beaker was transferred to $50 \mathrm{ml}$ volumetric flask and volume was made up to $50 \mathrm{ml}$ by $24 \%$ trichloroacetic acid. The content was gently mixed it and allowed to stand for 30-40 minutes for complete precipitation of fat and protein. Then, the content was filtered using Whatman filter paper 42 for estimation of urea as per the method for milk described by Bector et al. (1998). But, in case of dahi the filtrate was centrifuged at $3500 \mathrm{rpm}$ for $10 \mathrm{~min}$ (at $4^{\circ} \mathrm{C}$ ) and supernatant was used for urea estimation. Reconstituted milk was used for urea estimation in powder and same method was used for urea estimation in paneer whey (Bector et al., 1998).

\section{Storage study}

Sterilized milk prepared from both SW cow and Murrah buffalo were stored at $25^{\circ} \mathrm{C}$ and analyzed for fat, SNF and urea content in milk at 15 days interval till 90 days.

\section{Statistical analysis}

The results were treated for analysis of variance (ANOVA) (at $5 \%$ level of significance)

statistically using SAS Software (Version 5.4) and data was expressed as mean \pm standard error.

\section{Results and Discussion}

\section{Fat, SNF and urea in milk of different species}

Results showed (Table 1) that fat and SNF content in milk were significantly higher in Murrah and lower in KF. Significant difference was observed within breeds of cow with respect to fat and SNF content and it was significantly higher in TP and lower in KF whereas intermediate in SW. The urea content was found to be highest in Murrah buffalo and lowest in KF. However, nonsignificant difference in milk urea level was observed between Murrah, TP and SW. Similar results were observed by Sarkar et al. (2006).

\section{Effect of season on fat, SNF and level of urea in cow and buffalo milk}

It is evident from the Table 2 that average fat and SNF percentage in cow (TP, SW, KF) and buffalo (Murrah) milk were significantly $(\mathrm{p}<0.05)$ higher in summer followed by rainy and winter season. The increase in Fat and SNF content in summer season might be due to lower milk yield and those results of the present investigation are in close agreement with earlier findings (Gupta et al., 2010; Abbas et al., 2014).

Urea concentration in milk significantly changes during different seasons. Urea content in milk was observed to be higher $(\mathrm{p}<0.05)$ in winter season as compared to summer and rainy season in both species. A similar trend has been reported previously by various workers (Yoon et al.,2004; Marai and Haeeb, 2010). Urea content in milk was higher in winter which may be due to availability of green fodder whereas in summer season, 
insufficient availability of green fodder or heat stress affected the urea concentration.

\section{Effect of stage of lactation on fat, SNF, milk yield and milk urea concentration}

The colostrum was collected after calving and analysed for fat (\%), SNF (\%), urea content and milk yield. It is evident from Table 3 and 4 that fat and SNF content were higher in colostrum than normal milk in both species.

However, the urea content in colostrum of SW and Murrah was significantly $(\mathrm{p}<0.05)$ lower than normal milk which may be due to higher amount of protein content in colostrum or low milk yield or energy deficient condition immediately after calving.

It is evident from the Table 3 and 4 that there was a significant difference $(\mathrm{p}<0.05)$ in fat, SNF, milk yield and urea content in milk was observed during different lactation stage of Sahiwal and Murrah. It can be seen from Table 3 that the fat and SNF content in milk of Sahiwal cow was significantly decreased from $0^{\text {th }}$ day to $75^{\text {th }}$ day, thereafter it increased significantly till $195^{\text {th }}$ day. Similar trend was also observed in case of milk of Murrah buffalo. The fat and SNF content was found to decrease significantly from $0^{\text {th }}$ day to $60^{\text {th }}$ day, then it increased till $240^{\text {th }}$ day. Our observations are in close agreement with previous study carried by HenaoVelásquezet al. (2014). They observed that highest fat percentages was found in colostrum, followed by a decline during the first 2 months of lactation, then a progressive increase in lactation progresses.

Table 3 and 4 reveal significant difference $(\mathrm{p}<0.05)$ in milk yield during lactation period of Shahiwal cow and Murrah buffalo. The result showed that milk yield increased significantly from $0^{\text {th }}$ day to $75^{\text {th }}$ day, thereafter it decreased significantly till $195^{\text {th }}$ day in Sahiwal milk. Similar trend was also observed in milk of Murrah buffalo and the results showed that, the milk yield increased significantly from $0^{\text {th }}$ day to $60^{\text {th }}$ day, then it decreased significantly till $240^{\text {th }}$ day.

The level of urea in milk of SW and Murrah was found to be significantly different $(\mathrm{p}<0.05)$ during stage of lactation. Urea concentration in milk was significantly $(p<0.05)$ higher in $2^{\text {nd }}$ to $3^{\text {rd }}$ month after calving then it significantly decreased in both species. During lactation period the level of milk urea was found to be lower in first month as compared to rest of period. A similar trend of milk urea has been reported by Yoon et al. (2004) during lactation. The low urea content in early stages of lactation was probably due to the fact that animals were on energy deficient condition during this period (Dominic et al., 2014).

Table 1 Average fat, SNF and urea content in milk of different species

\begin{tabular}{lllrl}
\hline Species & Breed & Fat (\%) & SNF (\%) & $\begin{array}{c}\text { Urea } \\
(\mathrm{mg} / 100 \mathrm{ml})\end{array}$ \\
\hline Buffalo & Murrah (M) & $7.43 \pm 0.17^{\mathrm{a}}$ & $9.84 \pm 0.6^{\mathrm{a}}$ & $41.38 \pm 4.06^{\mathrm{a}}$ \\
Cow & Tarparkar (TP) & $5.14 \pm 0.11^{\mathrm{b}}$ & $9.34 \pm 0.17^{\mathrm{b}}$ & $40.85 \pm 2.67^{\mathrm{a}}$ \\
& Sahiwal (SW) & $4.69 \pm 0.09^{\mathrm{c}}$ & $9.06 \pm 0.01^{\mathrm{bc}}$ & $38.2 \pm 1.81^{\mathrm{a}}$ \\
& Karan Fries (KF) & $3.88 \pm 0.08^{\mathrm{d}}$ & $8.86 \pm 0.09^{\mathrm{c}}$ & $25.53 \pm 2.24^{\mathrm{b}}$ \\
\hline
\end{tabular}

Values are presented as means $\pm \operatorname{SEM}(n=3)$.

${ }^{\text {a-d }}$ Means within rows with different lowercase superscript are significantly different $(\mathrm{p}<0.05)$ from each other.

Table 2 Seasonal variation of fat, SNF and urea content in milk of different species

\begin{tabular}{|c|c|c|c|c|c|}
\hline$\overline{\text { Species }}$ & Breeds & Season & Fat (\%) & SNF (\%) & $\begin{array}{c}\text { Urea } \\
(\mathrm{mg} / 100 \mathrm{ml})\end{array}$ \\
\hline \multirow[t]{2}{*}{$\overline{\text { Buffalo }}$} & Murrah & Winter & $7.1 \pm 0.12^{b}$ & $9.75 \pm 0.03^{\mathrm{bc}}$ & $49.22 \pm 1.75^{\mathrm{a}}$ \\
\hline & & Summer & $7.70 \pm 0.03^{\mathrm{a}}$ & $9.94 \pm 0.04^{\mathrm{a}}$ & $35.6 \pm 1.45^{\mathrm{cd}}$ \\
\hline \multirow[t]{7}{*}{ Cow } & Tarparkar & Winter & $4.95 \pm 0.03^{\mathrm{de}}$ & $9.035 \pm 0.07^{\mathrm{e}}$ & $46.02 \pm 1.73^{\mathrm{ab}}$ \\
\hline & & Summer & $5.33 \pm 0.12^{c}$ & $9.64 \pm 0.04^{\mathrm{c}}$ & $37.09 \pm 1.13^{\mathrm{cd}}$ \\
\hline & & Summer & $4.83 \pm 0.06^{\mathrm{e}}$ & $9.23 \pm 0.10^{\mathrm{d}}$ & $35.13 \pm 2.31^{\mathrm{d}}$ \\
\hline & & Rainy & $4.70 \pm 0.17^{\mathrm{ef}}$ & $9.048 \pm 0.08^{\mathrm{e}}$ & $38.06 \pm 2.31^{\mathrm{cd}}$ \\
\hline & Karan Fries & Winter & $3.77 \pm 0.04^{\mathrm{gh}}$ & $8.74 \pm 0.03^{f}$ & $29.40 \pm 3.18^{\mathrm{e}}$ \\
\hline & & Summer & $4.04 \pm 0.09^{\mathrm{g}}$ & $9.04 \pm 0.04^{\mathrm{e}}$ & $21.62 \pm 2.02^{\mathrm{f}}$ \\
\hline & & Rainy & $3.83 \pm 0.04^{\mathrm{gh}}$ & $8.81 \pm 0.05^{\mathrm{f}}$ & $25.57 \pm 0.87^{\mathrm{ef}}$ \\
\hline
\end{tabular}

Values are presented as means $\pm \operatorname{SEM}(n=3)$.

${ }^{\mathrm{a}-\mathrm{h}}$ Means within rows with different lowercase superscript are significantly different $(\mathrm{p}<0.05)$ from each other. 
Overall observation (Table 3 and 4) showed that fat, SNF, milk yield and milk urea level were influenced by stage of lactation. During the lactation period, negative relationship was observed between milk urea, fat and SNF content; whereas positive relationship was observed between urea content and milk yield. A similar trend has been reported by earlier workers (Johnson and Young, 2003; Arunvipaset al., 2003; Henao-Velásquezet al., 2014).

\section{Effect of various processing treatments on fat, SNF and urea content of milk}

Table 3 Effect of stage of lactation on fat, SNF, milk yield and urea content in Sahiwal cow milk

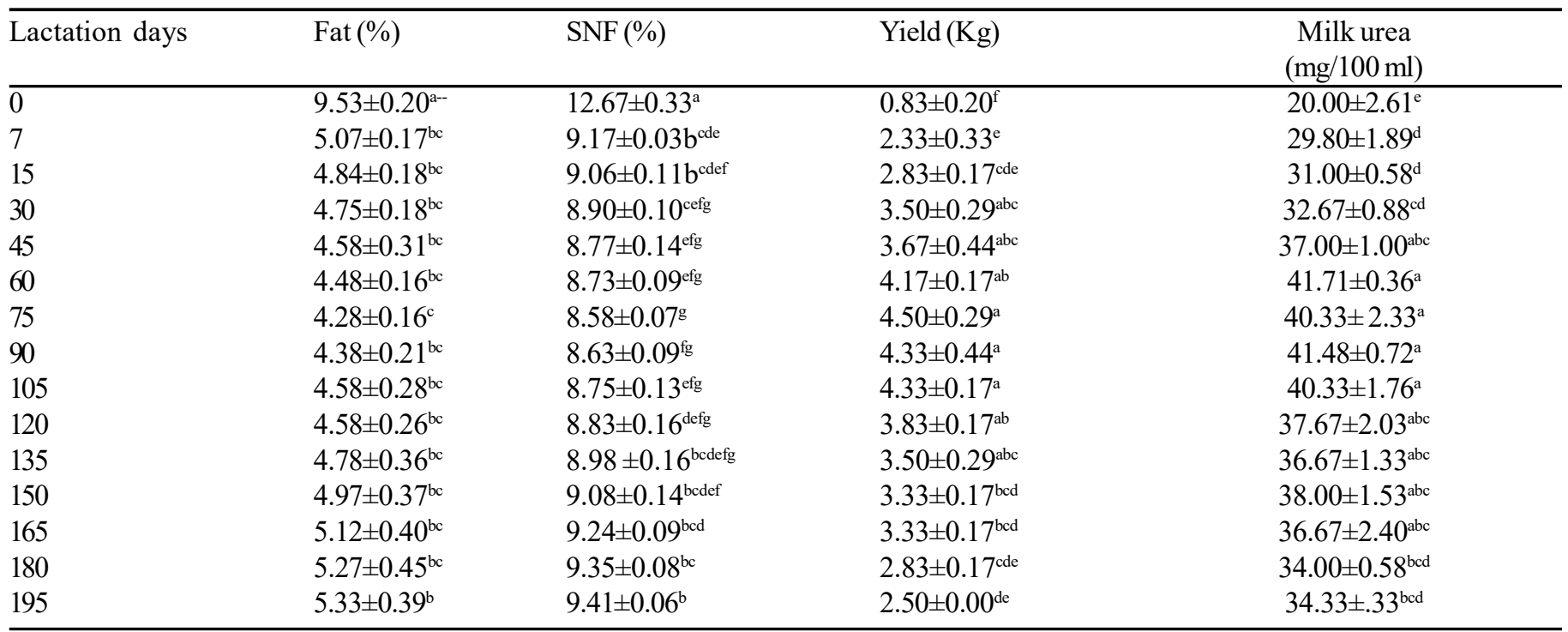

Values are presented as means $\pm \operatorname{SEM}(n=3)$.

a-g Means within rows with different lowercase superscript are significantly different $(\mathrm{p}<0.05)$ from each other.

Table 4 Effect of stage of lactation on fat, SNF, milk yield and urea content in Murrah buffalo milk

\begin{tabular}{|c|c|c|c|c|}
\hline $\begin{array}{l}\text { Lactation } \\
\text { days }\end{array}$ & Fat (\%) & SNF (\%) & Yield (Kg) & $\begin{array}{l}\text { Milk urea } \\
(\mathrm{mg} / 100 \mathrm{ml})\end{array}$ \\
\hline$\overline{0}$ & $12.00 \pm 0.58^{\mathrm{a}}$ & $14.67 \pm 0.33^{a}$ & $1.33 \pm 0.17^{f}$ & $22.03 \pm 3.04^{\mathrm{e}}$ \\
\hline 7 & $8.30 \pm 0.21^{\text {cde }}$ & $9.97 \pm 0.03^{\mathrm{bcd}}$ & $3.67 \pm 0.83^{\text {cde }}$ & $29.47 \pm 2.98 \mathrm{de}$ \\
\hline 30 & $7.20 \pm 0.15^{\text {fgh }}$ & $9.61 \pm 0.01^{\text {defghi }}$ & $5.50 \pm 0.58^{\mathrm{abc}}$ & $39.01 \pm 0.88^{\text {cde }}$ \\
\hline 45 & $6.70 \pm 0.17^{\mathrm{gh}}$ & $9.44 \pm 0.02^{\text {fgh }}$ & $6.50 \pm 0.76^{\mathrm{a}}$ & $46.30 \pm 0.93^{\mathrm{ab}}$ \\
\hline 90 & $6.43 \pm 0.12^{\mathrm{h}}$ & $9.35 \pm 0.08^{\text {hig }}$ & $6.15 \pm 0.87^{\mathrm{ab}}$ & $47.33 \pm 2.40^{\mathrm{a}}$ \\
\hline 105 & $6.47 \pm 0.12^{\mathrm{h}}$ & $9.38 \pm 0.10^{\text {gh }}$ & $5.67 \pm 0.33^{\mathrm{abc}}$ & $45.00 \pm 2.52^{\mathrm{ab}}$ \\
\hline 120 & $6.85 \pm 0.26^{\mathrm{gh}}$ & $9.50 \pm 0.12^{\text {efghi }}$ & $5.27 \pm 0.60^{\mathrm{abcd}}$ & $42.14 \pm 1.57^{\mathrm{bc}}$ \\
\hline 135 & $7.10 \pm 0.35^{\text {egh }}$ & $9.56 \pm 0.11^{\text {efghi }}$ & $5.17 \pm 0.60^{\mathrm{abcd}}$ & $41.90 \pm 2.44^{\mathrm{bcd}}$ \\
\hline 150 & $7.33 \pm 0.38^{\mathrm{fgh}}$ & $9.65 \pm 0.13^{\text {defgh }}$ & $5.17 \pm 0.60^{\mathrm{abcd}}$ & $40.033 \pm 0.58^{\text {cde }}$ \\
\hline 210 & $8.73 \pm 0.32^{\mathrm{cbd}}$ & $9.95 \pm 0.03^{\mathrm{bcd}}$ & $3.83 \pm 0.44^{\text {cde }}$ & $38.41 \pm 0.71^{\text {cde }}$ \\
\hline 225 & $9.08 \pm 0.52^{\mathrm{bcd}}$ & $10.08 \pm 0.11^{\mathrm{bc}}$ & $3.17 \pm 0.33^{\mathrm{def}}$ & $37.00 \pm 1.15^{\mathrm{e}}$ \\
\hline 240 & $9.50 \pm 0.45^{\mathrm{bc}}$ & $10.17 \pm 0.09^{b}$ & $2.83 \pm 0.44^{\mathrm{ef}}$ & $37.33 \pm 0.33^{\text {ed }}$ \\
\hline
\end{tabular}

Values are presented as means $\pm \operatorname{SEM}(n=3)$.

${ }^{a-i}$ Means within rows with different lowercase superscript are significantly different $(p<0.05)$ from each other 
It is evident from the Table 5 that there non-significant difference $\mathrm{min}$ ) and sterilization treatment in milk of both species. However, in fat content was observed during pasteurization, boiling (for 2 there was significant $(p<0.05)$ increase during boiling for 5 min.

Table 5 Effect of processing treatments on fat, SNF and urea content in milk

\begin{tabular}{|c|c|c|c|c|c|}
\hline$\overline{\text { Species }}$ & Breed & Treatment & Fat (\%) & SNF (\%) & $\begin{array}{c}\text { Milk urea } \\
(\mathrm{mg} / 100 \mathrm{ml})\end{array}$ \\
\hline \multirow[t]{5}{*}{$\overline{\text { Buffalo }}$} & Murrah & $\begin{array}{l}\text { Control } \\
\text { (Raw milk) }\end{array}$ & $7.72 \pm 0.14^{b}$ & $9.74 \pm 0.13^{\text {bc }}$ & $43 \pm 3.51 b^{\text {cd }}$ \\
\hline & & $\begin{array}{l}\text { Pasteurization } \\
\left(63^{\circ} \mathrm{C} / 30 \mathrm{~min} .\right)\end{array}$ & $7.80 \pm 0.11^{\mathrm{b}}$ & $9.88 \pm 0.14^{\mathrm{bc}}$ & $50 \pm 4.16^{\mathrm{abc}}$ \\
\hline & & Boiling (2min.) & $8.00 \pm 0.05^{\mathrm{b}}$ & $10.29 \pm 0.05^{\mathrm{b}}$ & $51 \pm 4.16^{\mathrm{ab}}$ \\
\hline & & Boiling (5 min.) & $8.47 \pm 0.33^{\mathrm{a}}$ & $11.19 \pm 0.23^{\mathrm{a}}$ & $55.33 \pm 6.84^{\mathrm{a}}$ \\
\hline & & $\begin{array}{l}\text { Sterilization } \\
\left(121^{\circ} \mathrm{C} / 15 \mathrm{~min}\right)\end{array}$ & $7.90 \pm 0.15^{\mathrm{b}}$ & $9.91 \pm 0.07^{\mathrm{bc}}$ & $33.67 \pm 0.33^{\text {de }}$ \\
\hline \multirow[t]{5}{*}{ Cow } & Sahiwal & $\begin{array}{l}\text { Control } \\
\text { (Raw milk) }\end{array}$ & $4.80 \pm 0.21^{\mathrm{d}}$ & $9.01 \pm 0.19^{c}$ & $39.83 \pm 1.59^{\text {cde }}$ \\
\hline & & $\begin{array}{l}\text { Pasteurization } \\
\left(63^{\circ} \mathrm{C} / 30 \mathrm{~min} .\right)\end{array}$ & $4.88 \pm 0.23^{\mathrm{d}}$ & $9.15 \pm 0.19^{c}$ & $43.83 \pm 2.62^{\mathrm{bcd}}$ \\
\hline & & Boiling (2min.) & $5.13 \pm 0.19^{d}$ & $9.78 \pm 0.36^{\mathrm{bc}}$ & $48.33 \pm 1.76^{\mathrm{abc}}$ \\
\hline & & Boiling (5 min.) & $5.60 \pm 0.18^{c}$ & $10.42 \pm 0.37^{\mathrm{ab}}$ & $52.00 \pm 2.58^{\mathrm{ab}}$ \\
\hline & & $\begin{array}{l}\text { Sterilization } \\
\left(121^{\circ} \mathrm{C} / 15 \mathrm{~min}\right)\end{array}$ & $4.88 \pm 0.21^{\mathrm{d}}$ & $9.12 \pm 0.24^{\mathrm{c}}$ & $30.7 \pm 0.33^{\mathrm{e}}$ \\
\hline
\end{tabular}

Values are presented as means \pm SEM $(n=3)$.

${ }^{a-e}$ Means within rows with different lowercase superscript letters significantly different $(p<0.05)$ from each other.

Table 6 Effect of storage $\left(\right.$ at $\left.25^{\circ} \mathrm{C}\right)$ on fat, SNF and urea content in sterilized milk of Sahiwal cow

\begin{tabular}{llcc}
\hline $\begin{array}{l}\text { Storage Period } \\
\text { (days) }\end{array}$ & Fat $(\%)$ & SNF $(\%)$ & $\begin{array}{c}\text { Milk urea } \\
(\mathrm{mg} / 100 \mathrm{ml})\end{array}$ \\
\hline Control (Raw milk) & $4.80 \pm 0.21^{\mathrm{a}}$ & $9.01 \pm 0.24^{\mathrm{a}}$ & $39.83 \pm 1.53^{\mathrm{a}}$ \\
Sterilized milk(0 day) & $4.90 \pm 0.21^{\mathrm{a}}$ & $9.12 \pm 0.24^{\mathrm{a}}$ & $30.7 \pm 1.53^{\mathrm{ab}}$ \\
15 & $4.91 \pm 0.25^{\mathrm{a}}$ & $9.09 \pm 0.20^{\mathrm{a}}$ & $30.67 \pm 1.76^{\mathrm{ab}}$ \\
30 & $4.84 \pm 0.18^{\mathrm{a}}$ & $9.05 \pm 0.19^{\mathrm{a}}$ & $29.33 \pm 0.33^{\mathrm{ab}}$ \\
45 & $4.75 \pm 0.12^{\mathrm{a}}$ & $9.00 \pm 0.20^{\mathrm{a}}$ & $29.10 \pm 15^{\mathrm{ab}}$ \\
60 & $4.82 \pm 0.17^{\mathrm{a}}$ & $8.99 \pm 0.18^{\mathrm{a}}$ & $27.33 \pm 4.98^{\mathrm{b}}$ \\
75 & $4.74 \pm 0.11^{\mathrm{a}}$ & $8.94 \pm 0.17^{\mathrm{a}}$ & $27.19 \pm 7.55^{\mathrm{b}}$ \\
90 & $4.71 \pm 0.11^{\mathrm{a}}$ & $8.93 \pm 0.16^{\mathrm{a}}$ & $26.12 \pm 2.73^{\mathrm{b}}$ \\
\hline
\end{tabular}

Values are presented as means \pm SEM $(n=3)$.

${ }^{a-b}$ Means within rows with different lowercase superscript are significantly different $(p<0.05)$ from each other.

Table 7 Effect of storage (at $25^{\circ} \mathrm{C}$ ) on fat, SNF and urea content in sterilized milk of Murrah buffalo

\begin{tabular}{llcc}
\hline $\begin{array}{l}\text { Storage Period } \\
\text { (days) }\end{array}$ & Fat $(\%)$ & SNF $(\%)$ & $\begin{array}{c}\text { Milk urea } \\
(\mathrm{mg} / 100 \mathrm{ml})\end{array}$ \\
\hline Control (Raw milk) & $7.72 \pm 0.14^{\mathrm{a}}$ & $9.74 \pm 0.13^{\mathrm{a}}$ & $43 \pm 3.51^{\mathrm{a}}$ \\
sterilized milk (0 day) & $7.92 \pm 0.15^{\mathrm{a}}$ & $9.95 \pm 0.12^{\mathrm{a}}$ & $33.67 \pm 2.33^{\mathrm{ab}}$ \\
15 & $7.84 \pm 0.18^{\mathrm{a}}$ & $9.95 \pm 0.07^{\mathrm{a}}$ & $32.66 \pm 3.29^{\mathrm{ab}}$ \\
30 & $7.73 \pm 0.17^{\mathrm{a}}$ & $9.97 \pm 0.01^{\mathrm{a}}$ & $32.33 \pm 0.33^{\mathrm{ab}}$ \\
45 & $7.80 \pm 0.20^{\mathrm{a}}$ & $9.78 \pm 0.10^{\mathrm{a}}$ & $31.25 \pm 4.00^{\mathrm{ab}}$ \\
60 & $7.73 \pm 0.16^{\mathrm{a}}$ & $9.91 \pm 0.13^{\mathrm{a}}$ & $30.67 \pm 3.71^{\mathrm{b}}$ \\
75 & $7.67 \pm 0.15^{\mathrm{a}}$ & $9.79 \pm 0.12^{\mathrm{a}}$ & $30.67 \pm 5.49^{\mathrm{b}}$ \\
90 & $7.67 \pm 0.14^{\mathrm{a}}$ & $9.79 \pm 0.09^{\mathrm{a}}$ & $29.6 \pm 3.21^{\mathrm{b}}$ \\
\hline
\end{tabular}

Values are presented as means \pm SEM $(n=3)$.

${ }^{a-b}$ Means within rows with different lowercase superscript are significantly different $(p<0.05)$ from each other 
Table 8 Level of milk urea in raw milk and finished dairy products

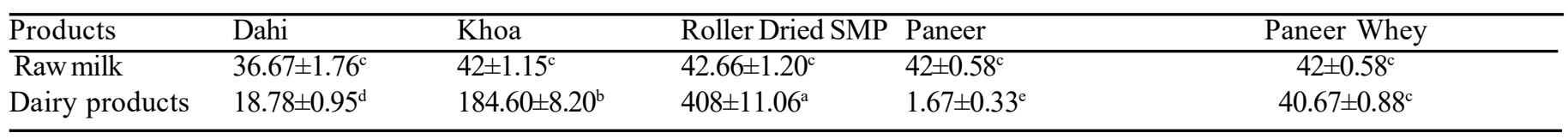

Values are presented as means $\pm \operatorname{SEM}(n=3)$.

${ }^{a-d}$ Means within rowswith different lowercase superscript are significantly different $(p<0.05)$ from each other

Table 9 Total solid (\%) content in raw milk and dairy products

\begin{tabular}{llc}
\hline Dairy Products & TS (\%) in Khoa & TS (\%) in SMP \\
\hline Initial raw milk & $16.58 \pm .78^{\mathrm{b}}$ & $10.12 \pm 0.58^{\mathrm{b}}$ \\
Dairy product & $66.72 \pm 2.1^{\mathrm{a}}$ & $97.2 \pm 0.65^{\mathrm{a}}$ \\
\hline
\end{tabular}

Values are presented as means $\pm \operatorname{SEM}(\mathrm{n}=3)$.

${ }^{a-b}$ Means within rows with different lowercase superscript are significantly different $(\mathrm{p}<0.05)$ from each other

Similarly no significant difference was observed in SNF content during pasteurization and sterilization treatment, whereas a significant $(\mathrm{p}<0.05)$ increase during boiling for 2 and $5 \mathrm{~min}$. it may be due to increased total solids of milk.

It can be seen from the Table 5 that there was a significant change in milk urea $(\mathrm{mg} / 100 \mathrm{ml})$ during various processing treatments. Urea content significantly increased during pasteurization $(p<0.05)$ and boiling treatments, but significantly decreased $(p<0.05)$ during sterilization treatment. Similar trend was also observed by Yeung et al.(2006) in case of sterilized milk. Significantly decrease in milk urea content during sterilization treatment may be due to decomposition of urea to carbonic acid, acetic acid, and ammonia at high time-temperature; Whereas increase in urea content during pasteurization and boiling treatments may be due to increased concentration of milk.

\section{Effect of storage on fat, SNF and urea content in sterilized milk}

It is evident from Table 6 and 7 that there was no significant $(\mathrm{p}<0.05)$ difference observed in fat and SNF content of sterilized milk up to 3 month at $25^{\circ} \mathrm{C}$. However, a significant $(p<0.05)$ decrease in urea content was observed with increased storage periods in both species of milk. There was a slight decrease in urea content till $45^{\text {th }}$ day of storage, but thereafter it decreased significantly in milk of both species. It might be due to hydrolysis of urea by urease enzyme which is produced by bacteria (Mora and Arioli, 2014).

\section{Effect on urea level during manufacturing of different dairy products}

It is evident from the Table 8 that there was significant difference $(\mathrm{p}<0.05)$ in urea content of raw milk and dahi. Milk urea concentration significantly $(\mathrm{p}<0.05)$ decreased from $36.67 \mathrm{mg} / 100$ $\mathrm{ml}$ to $18.78 \mathrm{mg} / 100 \mathrm{~g}$ during preparation of dahi. Results showed that decrease in urea content was to be tune of $50 \%$ in the process of dahi preparation. A similar observation has been reported previously by Vintila et al. (2011) for yoghurt. A decrease in concentration of urea during preparation of dahi may be due to hydrolysis of urea by urease enzymes, which is secreted by lactic acid bacteria during fermentation of milk in to dahi (Mora and Arioli, 2014).

The concentration of urea in raw milk and khoa was found to be $42 \mathrm{mg} / 100 \mathrm{ml}$ and $184.60 \mathrm{mg} / 100 \mathrm{~g}$, respectively (Table 8 ). During preparation of khoa, concentration of urea increased 4 to 5 times in comparison to raw milk; which may be due to increased concentration of total solid during preparation of khoa. Total solids content in raw milk and khoa was found to be $16.58 \%$ and $66.72 \%$, respectively (Table 9) and it clearly indicated that increase in total solids leads to increase in urea content.

The concentration of urea in raw milk and SMP was found to be $42.66 \mathrm{mg} / 100 \mathrm{ml}$ and $408 \mathrm{mg} / 100 \mathrm{~g}$, respectively. During preparation of SMP, urea concentration increased 9 to 10 times in comparison to raw milk; which may be due to increased solid concentration during preparation of SMP. Total solids content in raw milk and SMP was found to be 10.12 and $97.2 \%$, respectively (Table 9).

Similarly urea concentration in raw milk was found to be $42 \mathrm{mg} /$ $100 \mathrm{ml}$; whereas in paneer and whey found to be $1.67 \mathrm{mg} / 100 \mathrm{~g}$ and $42 \mathrm{mg} / 100 \mathrm{ml}$, respectively. The results showed that there was a no significant difference in urea content of raw milk and paneer whey because urea is water soluble (Myers, 2007).

\section{Conclusions}

The present study concluded that species, breed, season and stage of lactation significantly affected on milk urea level. During stage of lactation, urea level varied and a negative relationship was observed between urea, fat and SNF content, whereas positive relationship was observed between urea and milk yield. Processing treatments of milk significantly affected the urea level. During Pasteurization and boiling of milk, urea content increased whereas during sterilization, urea content decreased. Average 
urea content in dahi, khoa, SMP (Roller dried), paneer and paneer whey was found to be $18.78,184.60,408,1.67$ and $40.67 \mathrm{mg} / 100 \mathrm{~g}$, respectively. Urea content in milk was found to be lower than the prescribed legal limit i.e. $70 \mathrm{mg} / 100 \mathrm{ml}$. Based on the present study results can helpful to revised standard of milk urea and formulating the standard of urea limit in dairy products like dahi, khoa, SMP (roller dried) and paneer.

\section{References}

Abbas N, Zahoor T, Rahman ZU (2014) Physicochemical profile of milk from oxytocin injected buffaloes. Pak Vet J 34: 351-355

Abdallah MIS, Marouf HA, Bazal MS, Dawoud AS (2008) Determination of urea in cow's milk sold in Damietta governorate. J Egypt Vet Med Assoc 68: 1-6

Aneja RP, Mathur BN, Chandan RC, Banerjee AK (2002) Technology of Indian milk products. Dairy India Year book, New Delhi, India

Arunvipas P, Dohoo IR, Vanleeuwen JA, Keefe GP (2003) The effect of non-nutritional factors on milk urea nitrogen levels in dairy cows in Prince Edward Island. Preven Vet Medi 59: 83-93

Bector BS, Ram M, Singhal OP (1998) Rapid platform test for the determination of added urea in milk. Indian Dairyman 50: 59-62

De S (1991) Outlines of dairy technology. Oxford University Press, New Delhi

Dominic G, Ally K, Mercy AD, Gangadevi P,Murali, P (2014) Effect of energy supplementation during early lactation on milk composition and rumen fermentation parameters of crossbred dairy cows. Inter J Agric Food Sci Technol 5: 63-74

FSSR (2011) File No.2-15015/FSSAI/SP. Food Safety and Standards Authority of India (Ministry of Health and Family Welfare). FDA Bhavan, Kotla Road New Delhi-110002

Gupta R, Upadhyay PK, Singh VP, Verma SP (2010) Studies on variation of milk constituents of cross-breed cows during different season. The Asian J Anim Sci 4: 159-160

Henao-Velásquez A, David Múnera-Bedoya O, Cristina Herrera A, AgudeloTrujillo J, Fernando Cerón-Muñoz M (2014) Lactose and milk urea nitrogen: fluctuations during lactation in Holstein cows. Revista Brasileira de Zootecnia 43: 479-484

IS (1977) Fat Determination of milk by Gerber method.IS: 1224-2. Indian Standards Institution, New Delhi

IS (1995) Method for determination of moisture content in khoa. IS: 2785. Bureau of Indian Standards, New Delhi

IS (1982) Method for determination of SNF (Solids not fat) in milk by use of Lactometer. IS: 10083. Indian Standards Institution, New Delhi

IS (1997) Method for determination of moisture content in milk powder and similar products. IS: 11623, Bureau of Indian Standards, New Delhi

Johnson RG, Young AJ (2003) The association between milk urea nitrogen and DHI production variables in western commercial dairy herds. $\mathrm{J}$ Dairy Sci 86: 3008-3015

Marai IFM, Haeeb AAM (2010) Buffalo's biological functions as affected by heat stress. Livest Sci 127: 89-109

Myers RL (2007) The 100 most important chemical compounds: a reference guide: British Library Cataloguing, London, pp. 288

Mora D, Arioli S (2014) Microbial Urease in Health and Disease. PLoS Pathog 10: e1004472

Sarkar U, Gupta AK, Sarkar V, Mohanty TK, Raina VS, Prasad S (2006) Factor affecting test day milk yield and milk composition in dairy animals. J Dairying, Food Home Sci 25: 129-132

Singh P, Gandhi N (2015) Milk preservatives and adulterants: processing, regulatory and safety issues. Food Reviews Int J 31: 236-261

Vintila C, Marcu A (2011) Milk urea disappears during milk processing in to cheese. Sci Pap Anim Sci Biotechnol 44: 455-457

Yeung C-Y, Lee H-C, Lin S-P, Yang Y-C, Huang F-Y, Chuang C-K (2006) Negative effect of heat sterilization on the free amino acid concentrations in infant formula. Eur J Clinl Nutr 60: 136-141

Yoon JT, Lee JH, Kim CK, Chung YC (2004) Effects of milk production, season, parity and lactation period on variations of milk urea nitrogen concentration and milk components of Holstein dairy cows. AsianAustr J Anim Sci 17: 479-484 